УДК 78.03

DOI https://doi.org/10.31723/2524-0447-2021-32-2-6

\author{
Чжсан Юань
}

ORCID: 0000-0002-1561-9805

аспірант творчої аспірантури

Національної музичної академії України імені П. І. Чайковського

uadgfymb@gmail.com

\title{
МОТЕТ ЯК «ВІДКРИТА ФОРМА»: КОНЦЕПЦІЯ ПЕРЕТВОРЕННЯ В ДУХОВНІЙ МУЗИЦІ АНТОНА БРУКНЕРА
}

Мета роботи - виявлення природи музичної образності в пізніх духовних мотетах А. Брукнера в аспекті втілення композитором сакральної символіки. Методологія дослідження має комплексний характер, грунтується на поєднанні засад культурологічного, семантичного й історико-музикознавчого аналізу, які дають змогу глибше розкрити жсанрово-стильову специфіку хорової творчості А. Брукнера. Наукова новизна - на базі актуальних документально-історичних даних, а також сучасних аналітичних підходів до хорової спадщини A. Брукнера виявлено нові виконавські акценти в інтерпретації пізніх духовних мотетів композитора. Висновки. На матеріалі обраних пізніх мотетів А. Брукнера проаналізовано ключові принципи роботи композитора із сакральним текстом. Підкреслено, що для композитора використання релігійної символіки в хорових творах було органічною частиною творчого процесу. Через особливості службової діяльності А. Брукнер створював мотети з урахуванням їхньої ролі в церковному богослужінні. Для сучасних виконавців, які об'єктивно дистанційовані від иерковної практики, авторський задум композитора потребує розшифрування. Найважливішим ключем до розуміння художньої ідеї мотетів виступають їхні фінали. Зазначено, що проблема брукнерівського хорового фіналу має прямий стосунок до феномену музичної процесуальності. Наголошується на принципово іншому відчутті часу, що діє в духовних творах композитора: фінальні розділи мотетів не замикають течію музики, а приводять до тієї точки, де музика мислиться такою, що «вічно триває». Завдяки безперервності становлення музичної думки в середині сакрального тексту виникає феномен часу, коли через набуття людиною внутрішньої цілісності розкривається ї̈ власна нескінченність. Мотети А. Брукнера утворюють міцний зв'язок між багатовіковою католицькою традицією, носієм якої був композитор, і актуальними иінностями сьогодення.

Ключові слова: духовна музика, мотет, сакральний текст, інтонаційна драматургія, духовне перетворення.

(C) Чжан Юань, 2021 
Yuan Zhang, Postgraduate Student of Creative Graduate School of the Ukrainian National Tchaikovsky Academy of Music

Motet as an "open form": the concept of transformation in the spiritual music of Anton Bruckner

Research objective. Revealing the nature of musical imagery in the late spiritual motets of Anton Bruckner in the aspect of the composer's embodiment of sacred symbolism. The methodology of the research has a complex character, it is based on a combination of principles of culturological, semantic, historical and musicological analysis, which allow to reveal more deeply the genre and style specifics of A. Bruckner's choral work. The scientific novelty. On the basis of up-to-date documentary-historical data, as well as modern analytical approaches to Bruckner's choral heritage, new performance accents in the interpretation of the composer's late spiritual motets have been revealed. Conclusions. The key principles of the composer's work with the sacred text are analyzed on the basis of the selected late motets by A. Bruckner. It is emphasized that for the composer the use of religious symbols in choral compositions was an organic part of the creative process. Due to the peculiarities of his mass, Bruckner created motets, taking into account their role in church worship. For modern performers, who are objectively distanced from church practice, the author's idea of the composer needs to be deciphered. The most important keys to understanding the artistic idea of motets are their finals. It is noted that the problem of Bruckner's choral finale is directly related to the phenomenon of musical procedurality. Emphasis is placed on a fundamentally different sense of time, which operates in the spiritual compositions of the composer: the final sections of the motets do not close the flow of music, but lead to the point where the music is thought to be "forever". Due to the continuity of the formation of musical thought in the middle of the sacred text there appears a phenomenon of time, when through the acquisition of a person's inner integrity, his own infinity reveals. Bruckner's motets form a strong link between the centuries-old Catholic tradition of the composer and the current values of today.

Key words: spiritual music, motet, sacral text, intonational drama, spiritual transfiguration.

Актуальність теми дослідження. Духовні константи життя та творчості Антона Брукнера глибоко досліджені як закордонними, так і українськими істориками. Красномовною $€$ низка останніх дисертаційних досліджень, присвячених хоровій спадщині композитора: «Духовна музика Антона Брукнера» К. Хоуї (1969 р.) [20], матеріали якої увійшли до його двотомної монографії (2002 р.) [21; 22], «Соборность как идеал жизни и творчества Антона Брукнера (социальнофилософский анализ)» Н. Решетило (2011 р.) [16], «Церковна музика Антона Брукнера» Ф. Фрайсберга (2016 р.) [19], «Церковная музыка Антона Брукнера: к проблеме исторических 
связей» Д. Локотьянової (2018р.) [11]. Цей список доповнюють численні статті з фахових проблем хорового доробку композитора - А. Бібікової [3], О. Іванової [7], А. Колдаєвої [8], О. Халєєвої [17] та інших. Важливо підкреслити, що в «наймолодшій» роботі української авторки А. Дробиш «Духовна музика Антона Брукнера: жанрово-стильові особливості» (2021 р.) [5] - знову порушуються питання брукнерівського світосприйняття. Тож, зацікавленість хоровими опусами композитора активно зростає й набуває багатовекторного характеру.

У контексті заявленої проблеми поштовхом для роздумів можна вважати заключну фразу дисертації Д. Локотьянової: «Присвячуючи всю свою творчість <..> Творцеві, композитор завжди «перебував усередині буттєвої розмови». Його діалог із Ним розпочався від начала творчого шляху, щоб продовжитися й тривати вічно» [11, с. 138]. Музикознавиця підсумовує своє дослідження цією тезою, ми ж з неї починаємо.

Ніби просте, майже шкільне, завдання: «виконати так, як задумав композитор», щодо А. Брукнера обертається великою проблемою через те, що художній задум будь-якого з його мотетів (так само, як і решти духовних творів) укорінено в найглибших шарах світорозуміння автора. Як саме задумав А. Брукнер? Що вважати точкою відліку у виконавському трактуванні мотетів? Текст або наявність чи відсутність григоріанського хоралу в основі цілого, або жанрово-контекстні зв'язки? На наш погляд, ключем до розуміння духовних опусів А. Брукнера, якого не випадково Ернст Курт назвав композитором-містиком [9], у широкому сенсі може слугувати принцип подібності, або співзвуччя: ми чуємо в музиці те, що можемо почути. Чи має право на існування у виконавській практиці такий інтуїтивно-містичний підхід до творчості А. Брукнера? На нашу думку, так. Навіть більше, без особистісного проживання сакрального сенсу виконавцем інтерпретація творів композитора була б неможливою. Попри наявну суб'єктивність такого підходу, він, безумовно, відкриває новий сенс музики А. Брукнера. Причому тією ж мірою, що й інші підходи: документально-біографічний (Ф. Фрайсбрег, К. Хоуї), жанрово-історичний (Д. Локотьянова), культурологічний (Н. Решетило), богословський (А. Дробиш).

Відомо, що А. Брукнер створював свої мотети, орієнтуючись на цілком конкретні умови виконання: місце, час, 
а іноді й склад учасників. 3 урахуванням такої вкрай важливої складової частини хорової творчості композитора, як зв'язок із церковним ужитком, постає проблема концертного виконання мотетів. У виборі текстів для своїх майбутніх хорів А. Брукнер був обмежений їхньою функцією в літургійній службі. Проте він був вільний у сфері музичної інтерпретації першоджерела. Натомість виконавець перебуває в ситуації, коли лише художній контекст - музична інтонація - виступає носієм сенсу. Отже, актуальність обраної теми статті зумовлена необхідністю дослідити сутнісні основи музичної драматургії обраних мотетів та співвіднести їхній художній задум з умовами сучасної концертної практики.

Мета дослідження - виявити природу музичної образності в пізніх духовних мотетах А. Брукнера в аспекті відтворення композитором сакральної символіки. Матеріалом дослідження обрано два мотети, широко представлені в хоровому репертуарі європейських колективів: Os justi (WAB 30) i Christus factus est (WAB 11). Пріоритетними є аудіо- та відеозаписи останнього двадцятиліття ${ }^{1}$.

Наукова новизна. На основі актуальних документально-історичних даних, а також сучасних аналітичних підходів до хорової спадщини Антона Брукнера виявлено й аргументовано нові виконавські акценти в пізніх мотетах композитора.

Виклад основного матеріалу. Як відомо, існують різні принципи класифікації мотетів: за текстовими ознаками, за способом викладу, за структурними компонентами. А. Колдаєва ретельно аналізує жанрову природу мотету, поляризуючи німецьку та латинську традиції [8, с. 262]. Нагадаємо, що витоки латинського мотету сягають доби Середньовіччя. У XVI ст. мотет досяг свого класичного синтезу в контексті

1 У XXI ст. обидва мотети широко виконуються різними хорами. Ось деякі з найбільш яскравих аудіоверсій:

Hans-Christoph Rademann, NDR Chor Hamburg, Anton Bruckner: Ave Maria - Carus 83.151, 2000;

Stephen Layton, Polyphony Choir, Bruckner: Mass in E minor \& Motets - CD: Hyperion CDA 67629, 2007;

Erwin Ortner, Arnold Schoenberg Chor, Anton Bruckner: Tantum ergo CD: ASC Edition 3, issue of the choir, 2008

Otto Kargl, Domkantorei St. Pulten, Cappela Nova Graz, Bruckner: Messe e-Moll, CD: ORF CD 3174, 2013;

Philipp Ahmann, MDR Rundfunkchor Leipzig, Anton Bruckner \& Michael Haydn - Motets - SACD: Pentatone PTC 5186 868, 2021. 
франко-фламандського стилю Жоскена Депре та його послідовників. Пізніше з'явилися різновиди жанру в Німеччині й Англії (антем). На німецькому грунті латинський мотет було видозмінено. На початку XVI ст. латинська традиція в деяких землях Німеччини перервалася внаслідок Реформаційного руху. Проте музично-композиційні прийоми латинських творів збереглися в німецьких композиціях, хоча тексти й було перетворено на діалекти. Звернення до мотету в XIX ст. пов'язано здебільшого 3 німецької традицією: у творчості Ф. Мендельсона, Р. Шумана та Й. Брамса кількісно переважають німецькомовні зразки жанру. До латинської традиції зверталися в основному композитори австрійської школи - Ф. Шуберт, А. Брукнер, а також Ф. Ліст. «Широке використання латинських текстів у музиці, - вказують дослідники, - легко пояснюється мелодикою латинської мови, іiі вічною та непереборною красою» [10, с. 7]. Отже, у композиторській практиці XIX ст. рівною мірою культивувалися обидва типи мотетів - німецькою та латинською мовами.

У Німеччині популярність мотету була багато в чому пов'язана з попереднім розвитком жанру у творчості Г. Щютца та Й.С. Баха 2 . Приблизно від 1830 р., як зазначається у словнику Гроува, «впливовий цециліанський рух прагнув активно замінити симфонічну музику віденської школи чистим стилем, заснованим на акапельних месах і мотетах пізнього Ренесансу» $[23]^{3}$. Як відомо, А. Брукнер також зробив свій внесок до цециліанського напряму, хоча й не був йому послідовно відданий ${ }^{4}$ Композитор належав до числа тих митців, які за своїм світоглядом тяжіли до католицького канону, тож композитор не симпатизував суворому й консервативному німецькому стилю. На відміну від німецьких мотетів Й. Брамса та Ф. Мендельсона, які зазнали більшою мірою впливу німецької хорової школи, зокрема бахівської традиції, композиції А. Брукнера на латинські тексти були пов'язані з більш

2 Німецькі мотети Людвіга Зенфля з'явилися ще на початку XVI ст. 3 У 1868 р. в Регенсбурзі було засновано церковне товариство Союз св. Цецилії, назване на згадку про конгрегації св. Цецилії, до якої належав Палестрина. Цециліанський рух стосувався реформи церковної музики, яка прагне відродити в XIX ст. в Австрії акапельний хоральний стиль доби Ренесансу.

4 Детальна інформація щодо цециліанських впливів у хоровій творчості А. Брукнера міститься в дисертації Д. Локотьянової [11]. 
прадавніми музичними шарами. Попри широку обізнаність музиканта у творчості німецьких барокових майстрів, композиційна модель, яку обирає для себе А. Брукнер, сягає доби Ренесансу. Ідеться насамперед про стиль Дж. Палестрини та представників франко-фламандської поліфонічної школи.

Мотети Антона Брукнера можна вважати деякою мірою «підручником» із вивчення релігійного світовідчуття композитора. Надзвичайно ємні за змістом, вони концентровано виражають не лише головну думку молитви, але й кожну з їі смислових віх. Фраза за фразою, ніби щабель за щаблем, відкривається весь шлях проживання композитором сакрального сенсу, закладеного в тексті.

Видатний католицький теолог XX ст. Карл Ранер (Karl Rahner) визначає містику як «випробування внутрішньої об’єднуючої зустрічі людини з божественною нескінченністю, яка підтримує і людину, і решту проявів буття» [15, с. 275]. Найбільш незбагненне та водночас найпотаємніше в мотетах А. Брукнера - це «діалог» композитора з Богом. Широко відомо, що вплив віри для композитора був всеосяжним, отже, якої б грані творчості митця ми не торкнулися, вона буде пронизана цінністю божественної Присутності. Однак, незважаючи на рясне розмаїття документальних фактів, що доводять глибоку релігійність А. Брукнера, зазирнути в серцевину особистого духовного досвіду композитора ми ніколи не зможемо. Залишається лише його музика 3 іiі здатністю до «трансцендентності» та «породження позамузичних асоціацій» (К. Зєнкін).

Особлива ясність і променистість притаманні мотету Os justi meditabitur (WAВ 30). Це - виразний приклад витонченої інтонаційної роботи А. Брукнера з текстом. Композитор не просто деталізує кожну фразу, заглиблюючись в іiі символіку, але й знаходить до 3-5 варіантів прочитання одного слова. Саме в цих «варіаціях» красномовно проступає ставлення А. Брукнера до того чи іншого вислову. На думку композитора, щось може бути сказано побіжно, а щось потребує багаторазового тлумачення.

Чотириголосна композиція градуалу Os justi (WAB 30) була написана в 1879 р. на прохання регента хору монастиря св. Флоріана Ігнаца Трауміхлера. Текст твору взятий із Псалма 37:30-31. Згідно з поясненням А. Брукнера, яке він сформулював у супровідному листі до I. Трауміхлеру, в Os justi 
застосовано цециліанські принципи: від самого початку градуалу виключено всі знаки альтерації, септакорди, квартсекстаккорди й інші сучасні засоби музичної мови: «Мотет є строго модальним: він починається та завершується в лідійському ладу, а середня частина містить фугато. У фінальному розділі використано давньогрецьку каденцію, що стихає повторами $F$-dur' ного акорду» [20, c. 60].

Відкривається мотет просвітленою, ніби споконвічною фразою Os justi (The mouth <..> / Уста <...>) $)^{5}$. Весь аксіоматичний сенс першої репліки псалма зібрано у стрункий масив тонічного тризвуку. Його пафос - у відсутності будьяких інших прочитань. А. Брукнер був справжнім майстром у такому «декларуванні істин». Протягом наступних тактів початкова фраза набуває ще більшої величі завдяки охопленню крайніх регістрів діапазону та поліфонічному переплетенню голосів. Розгортаєтеся безкрайня картина божественної краси і мудрості, яка існує поза і над людиною.

Зовсім інший тип музичного викладу А. Брукнер обирає в середньому розділі: et lingua ejus loquetur judicium (and his tongue speaks what is just / i язик його говорить справедливість). Рухоме фугато, у якому кожна з хорових партій виявляє свій повноправний і відчутний «голос», створює звуковий образ громади. Не вдаючись до звукозображальних прийомів, А. Брукнер проте виразно малює «світ дольний»: він контрастний і перебуває в постійному русі. Досить тривале розгортання тематичного матеріалу приводить до яскравої й насиченої кульмінації. Динамічна вершина вибудовується на слові judicium («справедливість»), тт. 40-42. Зауважимо, що в ладогармонічному відношенні каданси, що завершують перший і другий розділи, ідентичні $(G-d u r)$. Завдяки цьому на композиційному рівні формується стійкий взаємозв'язок понять sapientiam (мудрість) (т. 16) і judicium (справедливість).

5 Д. Локотьянова пропонує такий варіант перекладу з латинської мови: Уста праведника изрекают премудрость, и язык его произносит правду. Закон Бога его в сердие у него; не поколеблются стопы его [11, с. 260]. Наводимо також переклад А. Дробиш: Уста праведного кажуть мудрість, язик жке його промовляє про право, закон Бога його - у його сериі (Пс. 36:30-31) [5, с. 146]. 
Ідея божественної мудрості, що цілковито заповнює світ, отримує остаточне підтвердження у третьому розділі мотету. Генеральна пауза виразно підготовлює виклад головної думки твору - Lex Dei ejus in corde ipsius (The law of his God is in his heart / Закон Божий у його серці). Ця фраза - суть молитовного тексту, у неї А. Брукнер вкладає максимум сенсу й духовного трепету. Рух завмирає у строгому чотириголоссі. 3 поверненням до вихідного типу фактури відбувається символічне переключення у «світ горній». Дбайливо й обережно, слово за словом оформлюється в музиці ключова думка тексту. Якщо й можна говорити про особисте проживанні композитором молитви, то це відбувається саме тут. Уперше велична краса світобудови немов «наближається» до людини. У всіх голосах фактури багаторазово повторюється слово corde. У низхідному секвенційному русі все більшої сокровенності набуває інтонація lamento.

У фінальному розділі твору музичний розвиток ніби згортається: заключна фраза тексту et non supplantabuntur gressus ejus (and his feet do not falter / нога не здригнеться) будується за мінімального руху верхнього голосу. Усі три нижні голоси завмирають на тонічній гармонії. Підсумком музичного розвитку стає унісонне проведення мелодії григоріанського хоралу Alleluia. Через «голос» традиції А. Брукнер немов би закарбовує свою - і загальнолюдську - приналежність вищому світопорядку.

Загалом, музику мотету Os justi вирізняє дивовижна за якістю статика - статика, коли активний рух усередині кожного із двох умовних образних шарів не приводить до їхньої взаємодії. Співіснування стає основою філософської ідеї мотету.

Сучасні концепції творчості Антона Брукнера базуються на потужному історично-документальному фундаменті, завдяки чому європейські, американські й українські дослідники мають можливість грунтовно висвітлити найрізноманітніші аспекти духовної музики «великого органіста». Але всі вони ніби «звернені в минуле», а завданням цієї статті є «розпізнання» сучасного сенсу мотетів А. Брукнера. I в цьому плані високоінформативним є мотет Christus factus est, WAB 11 (1884 р.). Поряд із хорами Locus iste і Ave Maria названий твір входить до числа найпопулярніших опусів композитора. Відомо, що А. Брукнер 
тричі розробляв текст градуалу Christus factus est ${ }^{6}$. Уперше він трапляється як частина Messe for den Grbndonnerstag (WAB 9), написаної в 1844 р. Друге звернення до тексту відбулося в 1873 р.: Christus factus est, WAB 10, - це мотет ре мінор для восьмиголосного змішаного хору, трьох тромбонів і квінтету ad libitum. Третя версія Christus factus est, обрана для аналізу в даній роботі, - це мотет для хору a cappella ре мінор WAB 11, який було створено в 1884 р. Перше виконання композиції відбулося за півроку, 9 листопада, у Віденській музичній капелі (Wiener Hofmusikkapelle). А. Брукнер присвятив свій твір Оддо Лойдолу (Oddo Loidol), одному зі своїх учнів.

Надзвичайно складна в емоційному плані, із провалами i злетами, приголомшуючими генеральними паузами музика мотету Christus factus est утілює величезне бажання людини стати ближчою до Бога. Ось так, у буквальному сенсі - стати ближче і залишитися в Ньому назавжди. А. Брукнер буває іноді дивовижно прямолінійним у своїх прагненнях. Перед нами розгортається драматична картина духовної боротьби людини, зверненої всією силою своєї любові до Христа. Це - щира, хвороблива і дуже сучасна історія людського шляху. У ній наявна самотність, але вона дієва й позбавлене будь-якого натяку на романтичну тугу. Це - внутрішня самотність, сенс якої постає у проростанні особистої духовної сили. Конфлікт і біль, що переживає герой, жодним чином не зумовлені зовнішніми життєвими катаклізмами. «Події мотету взагалі не мають стосунку до навколишніх чинників. «Чи став я сьогодні ближчим до Бога хоч на півкроку? Чи знову впав?» - ось фундаментальні питання, які зумовлюють усю інтонаційну роботу в мотеті. Якщо замислитися, якими стражданнями та мріями жив А. Брукнер, то стає очевидним, що для композитора духовне начало - це не спокій та бездіяльність, не відстороненість і безликість. Це напружена робота - робота, яка жене людину від одного рішення до іншого, труд, який невпинно штовхає до саморозвитку, і цей процес не має кінця й зупинок. Ось вона - основа і першопричина динамічного напруження в мотеті Christus factus est.

6 Джерелом даного тексту є книга 3 Нового Завіту - Послання до філіп'ян [Флп. 2: 8, 9]. Також простежується зв'язок тексту ще із трьома книгами Нового Завіту, як-от: Євангеліє від Луки, Послання до римлян і Послання до Галатів Апостола Павла. Текст точно не відтворює жоден із біблійних віршів вказаних книг, але звідти запозичені окремі фрази [10, с. 156]. 
А тепер можна подивитися - фраза за фразою, - через які «терни» іде людина, щоб наблизитися до свого ідеалу того образу, яким хоче й повинен, на непохитне переконання А. Брукнера, стати кожен.

У монолітному звучанні першої фрази Christus factus est pro nobis (Christ became obedient for us / Христос став для нас) ${ }^{7}$ зосереджено імпульс майбутнього розвитку. Початок утаємничений - як і все найголовніше для А. Брукнера. На основі фігури catabasis вибудовується закінчена й самодостатня думка: Христос $\epsilon$, Він звернений до світу (pro nobis). Умиротворення від цієї непорушної істини створює особливу атмосферу очікування - трепетного і просвітленого. Дуже виразним є відхилення в кінці фрази в тональність VI ступеня (B-dur).

Наступна хорова репліка Obediens usque ad mortem (even to the death / слухняним до смерті) має зовсім інший характер немов із самого центру людського душі проростає усвідомлення позачасової значущості вихідної тези. У слові Obediens («слухняним») для композитора об’єдналися і шанування, i подяка, і нестримна жага стати подібним. Ця думка окриляє, надаючи сил. Звідси така рельєфність мелодичного малюнку, у якому головну роль відіграють низхідні октавні ходи, загострені пунктиром. Повноти сенсу фраза набуває на словах usque ad mortem, mortem autem crucis (even to the death, death on the cross / слухняним до смерті, смерті на хресті). Раптовий i різкий басовий хід по звуках тризвуку (спочатку зі стрибком вгору, а потім із нестримним рухом до нижньої межі діапазону F2, т. 13-15), прорізає звукову тканину. Але той пафос трагізму, який міг би розростися в музиці пізніх романтиків до гігантських розмірів, тут стиснуто до одного такту і немов

\footnotetext{
7 У перекладі Д. Локотьянової текст виглядає так:

Христос послужил нам

вплоть до своей

смерти на кресте.

И поэтому Бог вознес Его

и дал Ему Имя, которое превыше всякого имени [11, с. 256].

Наводимо також переклад А. Дробиш:

Він упокорив Себе,

будучи слухняним аж до смерти,

і то смерти хресної, тому й Бог повищив Його та дав Йому Ім'я, що вище над кожне ім'я (Фил. 2: 8-9) [5, с. 147].
} 
би викарбовано на камені. Ідеться про факт, який не підлягає людському обговоренню: mortem звучить коротко, велично й однозначно. Фразою mortem autem crucis немов замикається певне коло циклу. Тривале й променисте світіння заключного слова crucis (хрест) насичує музику відчуттям таїнства. Завдяки виразному модуляційному переходу в Des-dur i загальному затиханню символічно розкривається позаособистісна сутність зображуваної в тексті події.

Відбувається зупинка часу (т. 20). А. Брукнер вдається до генеральної паузи - прийому, який буде використаний удруге перед головною кульмінацією мотету. Ця зупинка - поворот. Уся подальша «дія» відбувається від імені людини. Хвилями, вибухами, падінням і відродженням сповнений наступний розділ форми. Починається складний і глибоко особистий шлях духовного перетворення.

Середній розділ, що відкривається фразою Propter quod et Deus (Therefore God / Ось чому Бог), контрастує на всіх стилістичних рівнях: від фактури до темпу й динаміки. Базовими тут є засоби мотивно-секвенційної розробки матеріалу. До цього додається дуже виразний рух хорових ліній - вони розвиваються у протилежному напрямку, стрімко розростаючись ушир. Кожна із хвиль завершується афектованим вигуком exaltavit illum (exalted him / підніс його). Музика наповнена радісним, навіть захопленим шануванням. Але це пафос викликаний не зовнішньою стороною історії імені Христа (Et dedit illi nomen (and gave him a name / I він дав йому ім'я, т. 29), а бажанням особистого служіння Богу.

Сокровенність мети А. Брукнера виразно проступає в заключній фразі градуалу Quod est super omne nomen (which is above all names / яке понад усяке ім'я, т. 33). Саме тут укорінено головний сенс сакрального тесту для композитора. Ця фраза стає центром усього змісту мотету. Навіть у кількісному відношенні вона охоплює понад половину всього музичного часу твору. Розгортається тривала, побудована у вигляді трьох динамічних хвиль, лінія наростання. Приголомшуюча кульмінація, якій передує генеральна пауза (тт. 56-57) стає, образно кажучи, точкою неповернення. Увесь хоровий масив у ритмічному розширенні сповільненою ходою невпинно спускається у нижній регістр. У священному імені (nomen) зійшлося все живе для людини: біль, співчуття, любов... Відбувається символічний розрив часу - мить перетворення, коли повернення 
назад стає неможливим. Це проживання містичної єдності з Богом є серцевиною мотету.

Кодовий розділ твору побудований на тонічному органному пункті і являє собою тривале кадансування (тт. 65-79). Поступове, ледь відчутне згортання всіх голосів повертає свідомість до початкової тези мотету - Christus factus est pro nobis, сенс якого відтепер назавжди залишиться живим... Ось таким чином, не змінюючи ні слова в канонічному тексті, А. Брукнер ніби «розмикає» форму мотету.

Висновки. Звертаючись до композиторської спадщини А. Брукнера, ми не лише задаємося «вічними» питаннями, але й отримуємо на них відповіді. Музика композитора центрована на ідеї духовного пошуку, тому ії цінність сьогодні $€$ неймовірно високою. Для виконавців важливо усвідомлювати, що лише через музичну інтонацію ми приходимо до розуміння сакральних знаків, закладених у тексті. Релігійна символіка була для А. Брукнера відкритим знанням унаслідок його безпосередньої богослужебної діяльності. Для сучасних виконавців, які об'єктивно дистанційовані від церковної практики, авторський задум композитора потребує розшифрування. Найважливішим ключем до розуміння художньої ідеї мотетів виступають їхні фінали. У трактуванні сучасних диригентів акцент на смисловому «продовженні» форми $є$ прикметою часу. Можна виділити низку імен музикантів, які тонко відчувають драматургічну специфіку брукнерівських малих композицій, - Ганс-Крістоф Радеманн (HansChristoph Rademann), Стівен Лейтон (Stephen Layton), Ервін Ортнер (Erwin Ortner), Отто Каргл (Otto Kargl), Філіп Ахманов (Philipp Ahmann), Найджел Шорт (Nigel Short).

Варто зазначити, що проблема брукнерівського хорового фіналу має прямий стосунок до феномену музичної процесуальності. $\mathrm{E}$ підстави говорити про принципово інше відчуття часу, що діє в духовних творах А. Брукнера, - часу, коли через набуття людиною внутрішньої цілісності розкривається іiі власна безкінечність. Аналізуючи симфонічний метод А. Брукнера, К. Зєнкін підкреслює принципову нескінченність «варіантного відтворення» у сонатних формах композитора, завдяки чому брукнерівські завершення часто не замикають течію музики, а «приводять до тієї точки, де музика мислиться такою, що вічно триваэ» [6]. Продовжуючи цю аналогію, можна сказати, що церковні хори А. Брукнера, 
як і симфонії, «прагнуть переконати у причетності до Всеєдності і пережити містеріальне сходження до неї» [6].

Духовні мотети, так щедро представлені в хоровому доробку Антона Брукнера, сьогодні відкриті для нового прочитання. Їхня музика утворює міцний зв'язок між багатовіковою католицькою традицією, чиїм носієм був композитор, i актуальними цінностями сьогодення. Завдяки цій унікальній властивості ми маємо можливість стати частиною великого світу брукнерівської філософії.

\section{СПИСОК ЛІТЕРАТУРИ}

1. Антонова С. Историзм музыкального мышления и его проявление в симфоническом творчестве Й. Брамса и А. Брукнера : автореф. дис. ... канд. искусствоведения: 17.00.02. Нижний Новгород, 2007. 27 c.

2. Баранец А. Мистика в христианской и мусульманской культуpax: компаративистский подход : дис. ... докт. филос. наук: 24.00.01. Ростов-на-Дону, 2000. 270 с.

3. Бибикова А. О композиционной модели месс Антона Брукнера. Вестник Православного Свято-Тихоновского гуманитарного университета. Серия V «Музыкальное искусство христианского мира». Москва, 2008. Вып. 2 (3). С. 113-136.

4. Дробиш А. Релігійний світогляд як основа творчості Антона Брукнера. Часопис національної музичної академії України імені П.I. Чайковського. 2016. № 1 (30). С. 65-73.

5. Дробиш А. Духовна музика Антона Брукнера: жанрово-стильові особливості : дис. ... канд. мистецтв.: 17.00.03. Київ, 2021. 203 с.

6. Зенкин К О симфонизме А. Брукнера и его внемузыкальных основаниях. Музыка в пространстве культуры. Ростов-на-Дону, 2005. Вып. 3. С. 37-59.

7. Иванова Е. Текст и музыка в мессах Брукнера: некоторые наблюдения. Музыкальная академия. 1997. № 2. С. 170-172.

8. Колдаева А. Латинский мотет в творчестве А. Брукнера: к вопросу о традиции и новаторстве. Проблемы музыкальной науки. 2013. № 2. C. 264-268.

9. Курт Э. Брукнер как мистик. Ното тusicus. Москва, 1999. C. $79-92$.

10. Лебедев С., Поспелова Р. Musica latina. Латинские тексты в музыке и музыкальной науке. Санкт-Петербург : Композитор, 2000. $256 \mathrm{c}$.

11. Локотьянова Д. Церковная музыка Антона Брукнера: К проблеме исторических связей : дис. ... канд. искусствовед. : 17.00.02. Москва, 2018. $321 \mathrm{c.}$

12. Маргитич O. Проблемы мистицизма и харизматического движения в современном католицизме. Научные ведомости. 
Серия «Философия. Социология. Право». 2014. № 22 (193). Вып. 30. C. $73-78$.

13. Новак Л. Понятие «обширности» в музыке Антона Брукнера. Музыкальная академия. 1997. № 2. С. 167-169.

14. Новак Л. Стиль симфонический и стиль церковный. Музыкальная академия. 1997. № 2. С. 159-166.

15. Рагнер К., Форгрімлер Г. Короткий теологічний словник. Львів, 1996. 663 с.

16. Решетило Н. Соборность как идеал жизни и творчества Антона Брукнера (социально-философский анализ) : автореф. дис. ... канд. филос. наук: 09.00.11. Краснодар, 2011. 23 с.

17. Халеева Е. Мотет в европейской музыкальной практике: пути развития : дис. ... канд. искусствовед.: 17.00.03. Харьков, 2007. 209 с.

18. Auer M. Anton Bruckner als Kirchenmusiker. Regensburg, 1927. $225 \mathrm{~s}$.

19. Freisberg F. Die Kirchenmusik Anton Bruckners. Ein Beitrag zum Verstдndnis der Entwicklung seiner kьnstlerischen Identitдt F. Freisberg : $\mathrm{Ph}$. D. dissertation. Universitzt des Saarlandes, Saarbrbcken, 2016. $380 \mathrm{~s}$.

20. Howie A. Crawford. Bruckner and the motet. The Cambridge Companion to Bruckner. Part 2 : Choral music / ed. by John Williamson. Cambridge University Press, 2004. P. 54-63.

21. Howie C. Anton Bruckner: From Ansfelden to Vienna : A Documentary Biography. Edwin Mellen Press, 2002. Vol. I. 356 p.

22. Howie C. Anton Bruckner: Trial, Tribulation and Triumph in Vienna : A Documentary Biography. Edwin Mellen Press, 2002. Vol. II. 423 p.

23. Motet. The New Grove Dictionary of Music and Musicians. Vol. 16. Martin y. Coll to Monn / ed. by Stanley Sadie, John Tyrrell. 2'nd ed. Oxford ; New York: Grove, 2001.

\section{REFERENCES}

1. Antonova, S.E. (2007). The historicism of musical thinking and its manifestation in the symphonic works of J. Brahms and A. Bruckner. [Istorizm muzykal'nogo myshleniya i yego proyavleniye v simfonicheskom tvorchestve I. Bramsa i A. Bruknera]. The dissertation author's abstract for gaining the degree of the Candidate of Art Criticism by specialty 17.00 .03 Music Art. Nizhny Novgorod, 27 p. [in Russian].

2. Baranets, A.A. Mysticism in Christian and Muslim Cultures: a Comparative Approach, DSc Diss., Rostov-on-Don, 2000. 270 p. [in Russian].

3. Bibikova, A.A. About the compositional model of Anton Bruckner's Mass [O kompozitsionnoy modeli mess Antona Bruknera]. Bulletin of the Orthodox St. Tikhon University for the Humanities. Series V: The Musical Art of Christendom. Issue. 2 (3). Moscow, 2008. P. 113-136 [in Russian].

4. Drobysh, A.A. Religious outlook as the basis of Anton Brockner's work [Relihiynyy svitohlyad yak osnova tvorchosti Antona Bruknera]. 
Journal of the Tchaikovsky National Music Academy of Ukraine [Chasopys Natsionalnoi muzychnoi akademii Ukrainy imeni P. I. Chaikovskoho]. Issue 1 (30). Kyiv, pp. 65-73 [in Ukrainian].

5. Drobysh, A.A. Sacred music of Anton Bruckner: genre and style features. The dissertation author's abstract for gaining the degree of the Candidate of Art Criticism by specialty 17.00.03 Music Art. Kyiv, 2021. 203 p.

6. Zenkin, K.V. About the symphony of A. Bruckner and his nonmusical foundations [O simfonizme A.Bruknera i ego vnemuzyikalnyih osnovaniyah]. Music in the space of culture. Rostov-on-Don, 2005. Issue 3. P. 37-59.

7. Ivanova, Ye.V. (1997). Text and music in the masses of Bruckner: some observations [Tekst i muzyka $\mathrm{v}$ messakh Bruknera: nekotoryye nablyudeniya]. Music Academi [Muzykal'naja akademiya]. Issue 2. Moscow, pp. 170-172 [in Russian].

8. Koldaeva, A.N. Latin motet in the work of A. Bruckner: on the question of tradition and innovation [Latinskiy motet $\mathrm{v}$ tvorchestve A. Bruknera: k voprosu o traditsii i novatorstve]. Problems of music science. 2013. № 2. pp. 264-268.

9. Kurth E. Bruckner kak mistik [Bruckner as a Mystic]. Homo musicus. Moscow, 1999, pp. 79-92.

10. Lebedev, S., Pospelova, R. Musica latina. Latinskie teksty v muzyke i muzikal'noy nauke [Musica Latina. Latin Texts in Music and Musicology]. Saint Petersburg : Kompozitor Press, 2000. 256 p. [in Russian].

11. Lokot'yanova, D.Ye. (2018). Church music by Anton Bruckner: to the problem of historical connections [Tserkovnaya muzyka Antona Bruknera: k probleme istoricheskikh svyazey]. Manuscript of Dissertation work for gaining the degree of the Candidate of Art Criticism by specialty 17.00.02 Music Art. Moscow, 321 p. [in Russian].

12. Margitich, O.I. Problems of mysticism and charismatic movement in modern Catholicism [Problemyi mistitsizma i harizmaticheskogo dvizheniya v sovremennom katolitsizme]. Scientific Bulletin. Philosophy series. Sociology. Right. 2014. № 22 (193). Issue 30. P. 73-78.

13. Novak, L. (1997). The concept of "vastness" in the music of Anton Bruckner [Ponyatiye "obshirnosti" v muzyke Antona Bruknera]. Music Academi [Muzykal'naja akademiya]. Issue 2, pp. 167-169 [in Russian].

14. Novak, L. (1997). Symphonic style and church style [Stil' simfonicheskiy i stil' tserkovnyy]. Music Academi [Muzykal'naja akademiya]. Issue 2, pp. 159-166 [in Russian].

15. Ragner, K., Forgrimler, G. Short theological dictionary [Korotkiy teologIchniy slovnik]. Lviv, 1996. $663 \mathrm{p}$.

16. Reshetilo, N.S. Sobornost as the ideal of the life and work of Anton Bruckner (social and philosophical analysis) [Sobornost' kak ideal zhizni i tvorchestva Antona Bruknera (sotsial'no-filosofskiy analiz)]. The dissertation author's abstract for gaining the degree of the Candidate of Philosophical Sciences : 09.00.11 Social Philosophy. Krasnodar, 23 p. [in Russian]. 
17. Haleeva, E.V. Motet in European musical practice: ways of development. The dissertation author's abstract for gaining the degree of the Candidate of Art Criticism by specialty 17.00.03 Music Art. Kharkiv, 2007. 209 p. $225 \mathrm{p}$.

18. Auer, M. Anton Bruckner als Kirchenmusiker. Regensburg, 1927.

19. Freisberg, F. Die Kirchenmusik Anton Bruckners. Ein Beitrag zum Verstдndnis der Entwicklung seiner kьnstlerischen Identitдt. Ph. D. dissertation. Universitдt des Saarlandes, Saarbrbcken, 2016. 380 p.

20. Howie, A. Crawford. Bruckner and the motet. The Cambridge Companion to Bruckner. Part 2: Choral music / ed. by John Williamson. Cambridge University Press, 2004, pp. 54-63.

21. Howie, C. Anton Bruckner: From Ansfelden to Vienna : A Documentary Biography. Volume I. Edwin Mellen Press, 2002. 356 p.

22. Howie, C. Anton Bruckner: Trial, Tribulation and Triumph in Vienna : A Documentary Biography. Volume II. Edwin Mellen Press, 2002. $423 \mathrm{p}$.

23. Motet. The New Grove Dictionary of Music and Musicians. Vol. 16. Martin y. Coll to Monn / ed. by Stanley Sadie, John Tyrrell. 2'nd ed. Oxford; New York : Grove, 2001. 